\title{
Personal uprightness as the just cause in Psalm 17: Afrocentric reflections
}



This essay situates study of the psalter within an African interpretational modality. Given the fact that western scholarship has dominated if not prescribed approaches to biblical texts demonstrable from the absence of African motifs in research by African students until recent times, this new opportunity for other perspectives invites contributions. As such the analysis of Psalm 17 here is such a contribution utilising a real-life African situation to show how that context can uniquely assist to illuminate biblical texts.

Intradisciplinary and/or interdisciplinary implications: The essay connotes social-justice and political African constructs in conversation with biblical analysis of an ancient Hebrew text. Practical and systematic theology are implied as well as African cultural studies with a decolonial agenda.

Keywords: justice; uprightness; Afrocentric; equity; fairness.

\section{Introduction}

During a recent visit to N'djamena, the capital city of the Republic of Chad, whilst enjoying lunch with a group of leaders, a rather heated debate broke out concerning a particular man from their neighbourhood. It turns out that he formerly was a prominent personality within government circles with a notoriety for being heavy-handed and unfairly disposed towards members of the opposition political party. As fate would have it, his fortunes turned for the worse after a fall out with the government leadership, leading to losing his position. Needless to say, he inevitably failed to secure any form of employment thereafter because of the reputation associated with his past. His business enterprises collapsed through hostile takeovers because he no longer enjoyed government protection. During my visit, he was bereaved and uncharacteristically the community went against their customary commiseration with him. When I asked why this was being performed, the men at the table said justice applies to the upright, implying until the man becomes humane in observable ways, he will continue to be shunned. I asked if he could appeal to court of law to secure his lost businesses, the statement was reiterated, and justice is for the upright.

The Chadian aphorism that personal uprightness is the basis for justice finds expression in Psalm 17 to illustrate how African events as an agent of the interpretation illuminate biblical texts (Adamo 2015:59-72; Bediako 1995:91-108; Coertze 2008:77-90). ${ }^{1}$ Adamo (2015) defines the agents of African hermeneutics as:

... a methodological resource that makes African social cultural contexts the subject of interpretation. This is a methodology that reappraises ancient biblical tradition and African world-views, cultures and life experiences, with the purpose of correcting the effect of the cultural, ideological conditioning to which Africa and Africans have been subjected in the business of biblical interpretation. It is the rereading of the Christian scripture from a premeditatedly Africentric1 perspective. (p. 62)

The proposed Afrocentric reading of this Psalm is a response to the predominance of Euro-American readings of biblical texts which routinely excluded African realities. In his introductory remarks to an article on this subject matter, Adamo (2007:21) describes his theological training as non-African in that it was devoid of African views and values that were either outrightly dismissed or demonised, whilst Western manners were inculcated and promoted. This is reflected in Holter's (2002) listing of doctoral dissertations in the Old Testament by African students from 1967 to 2000 which reveals the hegemonic hold of Western approaches. In a review

1.Bediako's seminal work provides the fertile ground on which the work of Adamo and decolonization actually thrive. Coertze, on the other hand, calls for the actual participation of African scholars in the translation work of the Bible into indigenous languages from which they have tended to be absent with the view to utilizing contextual knowledge for transmitting culturally accurate interpretive understandings. 
of this publication, Bediako (2004) particularises on the absence of African world views in the dissertations when he states that:

$[N]$ one shows serious use of the African context as a resource for interpretation or indicates that the African world, with its awareness of transcendence that is 'larger' than what the Western Enlightenment outlook allows for, can illuminate the Old Testament, probably because most dissertations were produced at Western institutions. (p. 138)

That said, even African scholars who studied on the continent were mostly under the supervision of missionaries and their scholarship defaulted to that of the instructors. ${ }^{2}$

In this article, Africanisation does not represent a rejectionist agenda of Euro-American readings per se, but a revisionist paradigm intended to critically register the agency of African realities and the African in the ongoing analysis of Psalm $17 .^{3}$ Adamo (2015) proposes:

[T]he rereading of the Christian scripture from a premeditatedly Africentric perspective. Specifically, it means that the analysis of the biblical text is done from the perspective of African world-view and culture. (p. 33)

This is in line with emerging works and various attempts, one of such was spearheaded by Holter (2006) mentioned above, towards an African hermeneutical approach to the study of the Hebrew Bible. ${ }^{4}$ The approaches in these studies fall under three categories, namely; 'Using Africa to Interpret the Old Testament', 'Using the Old Testament to Interpret Africa', and 'Finding Africa in the Old Testament'. This article falls under the first category with emphasis on a pragmatic approach that best serves the priorities of this research in line with Adamo's (2015:32) definition that

2.The endemic dependency of Africans on Eurocentric world view is best illustrated in a parallel exercise documented in Rankin's (2003:85-100) article on Christian imagery produced by African artists where designs were given by white missionaries imagery produced by African artists which did not take into consideration African traditions and symbolism. The design that were mostly utilized to decorate African churches were drawn from the late
medieval times. Interestingly, the Africanised versions of such imagery were mostly medieval times. Interestingly, the $A$ tri
taken to Europe as collector items.

3.Sumpter (2013) presents an important interpretational paper on the coherence of Psalms 15-24 which assists with situating significant self-contained sub-collection that is chiastically arranged and reveals how the manner in which the content of each psalm is 'expanded', the nature of the relation between the framing psalm $(15 ; 19 ; 24)$ and those that intervene and the significance of David and Zion. In short, he argues that the editors were concerned to situate David within his true theological context which provides an important point of contact for this study through which future readers are provided with a means for contextualizing their own faithful struggle, regardless of their shifting historical, cultural and institutional contexts.

4. Holter's publication has the following studies carried out between 2002 and 2006 as a sample of Africanisation of Old Testament studies: Knut Holter, 'Let My People a sample of Africanisation of Old Testament studies: Knut Holter, 'Let My People (pp. 1-18); Madipoane Masenya (ngwana' Mphahlele), 'Challenging Poverty (pp. 1-18); Madipoane Masenya (ngwana' Mphahlele), 'Challenging Poverty through Proverbs: An African Transformational Hermeneutic' (pp. 21-34); Lechion Peter Kimilike, 'Using African Proverbial Folklore to Understand the Holistic Poverty Eradication Framework in the Book of Proverbs' (pp. 35-49); Lechion Peter Kimilike 'The Poor Are Not Us! An Exploration into the Transforming Possibilities of Old Testament and African Proverbs on Poverty' (pp. 51-63); Willie van Heerden, 'Its [sic] on the Old Mat That One Weaves the New One: The Dialogue between African Proverbs and Biblical Texts' (pp. 65-77); Magdel Le Roux, 'Using the Old Testament to Interpret Africa: The Malagasy Religious Context' (pp. 81-96); Georges Razafindrakoto, 'The Old Testament outside the Realm of the Church: A Case from Madagascar' (pp. 97-110); Georges Razafindrakoto, 'The Malagasy Famadihan Ritual and the Old Testament' (pp, 111-130); Madipoane Masenya (ngwana' Ritual and the (1) (pp. 131-146); Willie van Heerden, 'Finding Africa in the Old Testament: Some Hermeneutical and Methodological Considerations' (pp. 149-176); Philip Lokel, 'Previously Unstoried Lives: The Case of Old Testament Cush and Its Relevance to Africa' (pp. 177-190), Philip Lokel, 'Moses and His Cushite Wife: Reading Number 12:1 with Undergraduate Students of Makerere University' (pp. 191-201); Magde
Le Roux, 'The Lemba: The "People of the Book" in Southern Africa' (pp. 203-214).
'African biblical hermeneutic(s) is the principle of interpretation of the Bible for transformation in Africa'. With that transformative agenda in mind, our attention to the text to highlight three aspects:

- a just cause is predicated on the prospect of being heard (Ps 17:1)

- a just cause is determinable for a worthy individual (17:2-12)

- a just cause is ultimately pacified through the attainment of divine likeness (17:13-15).

\section{Analysis}

\section{A just cause is predicated on the prospect of being heard Psalm 17:1}

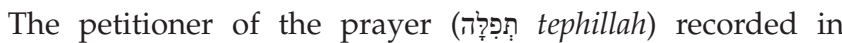
Psalm 17 identified in the superscription as David (Ps 17, 86, $90,92,142)$, opens with a triad of pleas $(17: 1){ }^{6}$ as a precursor to the significant space dedicated to his personal uprightness

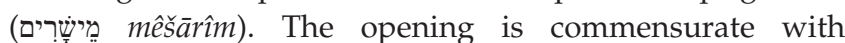
individual lament psalms ${ }^{7}$ in which divine audience is sought before the presentation of the complaint (see Ps 5:1-3; 27:7-9; $28: 1-2 ; 55: 1 ; 61: 1-2 ; 63: 1-2 ; 120: 1-2 ; 141: 1-2 ; 142: 1-2 ; 143: 1) .{ }^{8}$ However, in $17: 1$, the use of the imperative construct in the verbs entreating divine attention as well as the extended appeal (17:2) deviates from the 'the invocations in the Hebrew laments of the individual [that] are brief and direct' (Lenzi 2010:305). ${ }^{9}$ The intensity of the entreaty perhaps emanates from other situations where divine delays or abandonment have been experienced (Ps 13:1; 22:1; 27:9; $42: 1-3 ; 43: 2 ; 69: 1-3 ; 88: 1-2 ; 102: 1-2 ; 109: 1)$ and the poignancy of isolation motivates the need for intervention.

The fact that divine audience cannot be taken for granted is indicative of the privilege of being heard as the premise for a

\begin{abstract}
5.Psalm 17 has been variously structured with Grogan (2005) has a three-part structure 17:1-5 A Righteous Plea; 17:6-12 Plea for an Answer; 17:13-15 Assurance; which do: does not quite coincide with Bergant's (2013) 17:1-8 A prayer for Justice; 17:9-14 Attacks of Enemies; 17:15 Claim of Innocence; Waltner (2006) presents a four-part structure 17:1-5 Petition for a fair hearing; 17:6-12 Petition for Refuge from the Wicked; 17:13-14 Imprecatory Prayer for God's Judgement upon the enemy; 17:15 Expression of Hope; deClaisse-Walford, Jacobson and Tanner's (2014) three sections
of pleas 17:1-2; 17:6-9; 17:13-14; interspaced with a complaints 17:3-5; 17:10-12 and a declaration of trust. The approach in this article has been to somewhat simplify the structure by combing description of the problem with the appeal for help as well as appeal for help with confession of trust for pragmatic reasons.
\end{abstract}

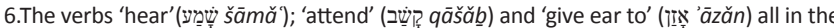
imperative construct represent an intensity in the exhortation. The first has the idea of registering a cause for being granted audience, the second a similar idea but with emphasis on listening carefully and the third even more emphatic with the idea to heed something. There is an observable progression in intensity and a build-up here.

7.The following are assumed to be individual laments in the Psalter $3 ; 5 ; 6 ; 7 ; 13 ; 17$ $22 ; 26 ; 27: 7-14 ; 28 ; 31 ; 39 ; 42 ; 43 ; 51 ; 55 ; 56 ; 57 ; 59 ; 61 ; 63 ; 69 ; 70 ; 71 ; 86 ; 88 ; 102$ $109 ; 120 ; 130 ; 140 ; 141 ; 142 ; 143$.

8.The nature of a lament is herein implied as stated by Brueggemann (1995:105): (1) Things are not right in the present arrangement. (2) They need not stay this way and can be changed. (3) The speaker will not accept then in this way. (4) It is God's obligation to change things.

9.Lenzi (2010:304-305) samples various invocations utilised in the laments of the individual which show the following: In most laments of the individual in the Hebrew Psalter, the invocation is simply hwhy, 'O Yahweh' (see, e.g. Ps 3:2; 6:2) or, as would be expected in the Elohistic Psalter, Myhl), 'O God' (see, e.g. Ps 43:1:51:3). Other invocations are just as short, consisting of a single word (Ps 59:2, yhl) ' $\mathrm{O}$ my god') or only slightly longer, made so by placing two very brief invocations in god'), or only slightly longer, made so by placing two very brief invocations in parallel in the opening line or two (see Ps 28:1, yrwc/hwhy, 'O Yahweh/my rock', 70:2, hwhy/Myhl), 'O God/O Yahweh'; 25:1-2, yhl)/hwhy, 'O Yahweh/my god'; and 130:1-2, ynd)/hwhy, 'O Yahweh/my lord'). The longest invocations consist of only
three words: Ps 5:2-3, which places hwhy in parallel with yhl)w yklm, 'my king and my god'; Ps 22:2-3, showing yl) yl), 'my god, my god', in parallel with yhl), 'O my my god'; Ps $22: 2-3$, showing $\mathrm{Yl}$ ) $\mathrm{yl}$ ), 'my god, my god', in parallel with yhl), 'O my
god'; and Ps 88:2 and its questionable formulation, yt(w\#y yhl) hwhy, 'O Yahweh, god of my salvation'. 
just cause. By definition, Hebrew laments of the individual represent a petitioner's quest for justice. Significantly, the concept צֶ (șédéq) used in 17:2 to depict the speaker's cause is utilised in the Hebrew Bible interchangeably with (mišpa $\bar{t}$ ) justice or vindication also in 17:2 which according to Younan (2011:26) has legal connotations as well as a bookending feature (17:15) or what Goldingay (2006:239) calls a quasi-judicial content of appeal from self-purported innocence. The terminal for justice as in 'the act of deciding a legal dispute or case or a state or condition of fairness in disputes' (Swanson 1997) lies in the prospect of being heard. Becket (2016) correctly points out:

The lament of the people typically contains the following component parts, albeit with variation in expression: an introductory petition to God for help, a complaint, a confession of trust in God, the specific petition (for God to hear, to save, and/or to punish), a rationale for God's action, and a vow to praise God for his solicited action. The individual lament incorporates all of these elements, with the addition of an assurance of being heard, and often, a double wish that God would intervene on the lamenter's behalf and contend against his enemies. (p. 210)

Divine audience as the primary and leading objective of the petitioner, we argue, is the starting point of any just cause, a privilege not always realised by those variously victimised by injustice.

\section{A just cause is determinable for a worthy individual 17:2-12}

Unlike other individual lament psalms where the speaker registers his complaint as quickly as he begins (e.g. Ps 3:1; 7:1; $43: 1 ; 64: 1 ; 69: 1 ; 86: 1$; etc.), Psalm 17:1-7 strategically builds up the case for personal uprightness as the basis for divine audience and predictably for intervention. The invocation of God by his covenantal name יהוה (yhwh) is motivated by the pervasive approach of assuming that personal uprightness as the justification for divine attention also commands divine arbitration. The statement that the prayer is from lips that are free of deliberately misleading is underscored by the injunction that divine justice or vindication the מֵישָָׁרים (mêšârîm) upright referring to the manner of life distinctive of the blameless (Wiseman 1999:417). The innocence with which the psalmist pleads is consistent with the category of psalms such as 7, 16, 35 and 139 that some scholars are beginning to recognise as a distinct classification (Bratcher \& Reyburn 1991).

The portraiture of worthiness or blamelessness dominates the verses that ensue firstly, by divine attestation in 17:3, and then through personal behaviour in 17:4. Divine substantiations of personal uprightness of the speaker emanate from subjection the view to try and learn the genuineness of an object by examination, or observing reaction to a standard, and in this case with the individual's heart as the object of the probing (Swanson 1997). Then also the speaker has been subjected to night check-ups; implying to pass in review, to muster, calling to account in order to establish state of affairs (Landes 2001). By the same token, the speaker has been exposed to seemingly severe $(s \bar{a} r a ̆ p \bar{p})$ refining a concept used of the removal of impurities in metal to purify it (Swanson 1997). Similar divine attestations of personal uprightness can be read in Psalm 26:1-3 in demonstration of loyalty to Yahweh. Psalm 17 unmistakably motivates personal uprightness for the grandeur cause - justice itself.

The self-attestation through personal behaviour begins with a statement of intent through the concept to plan, determine or resolve implying to think with the purpose of planning or deciding a course of action (Swanson 1997). The planned action is that of carefully watching his words thus accentuating his own behaviour culminating in claiming avoidance of the ways of the evildoers in 17:4. To maintain that equilibrium of uprightness, the lamenter requests divine support in 17:5 without which he recognises he may slip. In thinking of the stance taken here, Charney (2013) espouses that:

[T]he argument for the speaker's worthiness is especially powerful, dominating the content and expression in the psalm. As such, these speakers treat their innocence not as obvious but as a point in need of articulation and support ... the more innocent the speaker, the better the grounds for challenging God's neglect as a case of injustice. (p. 46)

Needless to say, 17:6 follows on with reiterating the plea to be heard (17:1-2), intentionally placed here as a deserved privilege or earned on the basis of the well-articulated personal uprightness. The appeal for divine (hěsěd unfailing kindness (17:7) for much-needed protection from his adversaries allows for the case of uprightness once again as the basis for such intervention. In fact, there is the bold presentation of God as the (môs $\left.\hat{s}^{a}{ }^{a}\right)$ deliverer as a reciprocal benefit of the חָָ (hâas $\bar{a}[h])$ those who take refuge in him, inferring to a relationship of mutual trust. That reciprocity of uprightness as deserving protection culminates in 17:8-9 with a request for divine enablement for the preservation the special relationship between the petitioner and Yahweh. Keil and Delitsch (1996:nn) describe the 'apple of Your eye' appellation (Deut 32:10; Pro 7:2; Zec 2:8) as an extrapolation of covenant relationship towards himself in which Jahve has placed David, and the relationship of love in which David stands to Jahve, fully justified (Keil \& Delitzsch 1996). Such a covenantal term of endearment followed by an active seeking of protection from the oppressors suitably situated 'under the shadow of your wings', a figure, taken from the eagle, which hides its young under its wing (Keil \& Delitzsch 1996). This is particularly significant in view of the impending threat from the antagonists here named as

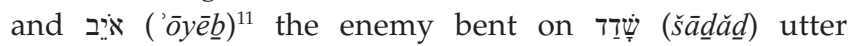
10.Pertaining to being evil with a focus on the guilt of violating a standard. 11.Refers to the hostile, opponents of an individual or a nation described by McComiskey (1999:36) as those whose defeat would be a mark of divine favour McComiskey $(1999: 36)$ as those whose defeat would be a mark of divine favour
( $2 \mathrm{Sm} 7: 9 ; 22: 18,41)$, or whose destruction is seen as a result of divine intervention (Jos 23:1; Jud 8:34; 1 Ks 8:46). 
destruction or ruin, hence the idea of being hemmed in derived from

The sense of the enemy's overwhelming presence and military tactics demonstrable of his mercilessness preoccupy 17:10-12. This is against the backdrop of the articulation of the psalmist's innocence in 17:3-9 in contrast to the blatant intemperance of the enemy. The enemy's modus operandi described therein depicts pitilessness (17:10), constriction (17:11) and predatory (17:12). Pitilessness emerges from the metaphorical description of the enemy's heart as (hêlěb) translated 'fat' in describing a callous heart (Ps 17:10; 73:7; 119:70) (Swanson 1997). That callous heart that is said to be closed סָגרוּ ( $g \bar{e} \cdot \hat{u} \underline{t}$ ) literature of something lifted up such as column of smoke; swelling of the sea (Whitaker et al. 1906), better translated as arrogant, to intensify the victimisation of the petitioner. The self-indulgence plaguing the enemy's hardened and proud disposition regresses into idea of constriction derived from the ideas of being surrounded סָרָ (sābăb $\underline{b})$ and crouching down נָָטָ $(n \bar{a} t \underline{a}(h))$. These verbs depict inability to proceed forward or backward on the one hand, and, on the other hand, of being cast to the ground because of the constrictive setup. With progress inhibited and pursuance intensified, the predatory instincts of the enemy are pretty pronounced. The use of the imagery of the lion ready to טָרָ (târăp $\bar{p})$ depicts violence as in:

$[T]$ o tear or mangle, that is, a ripping apart of soft tissue with sharp teeth, with a focus on a violent, abhorrent death (Ge 37:33a; 44:28a; 49:27; Ex 22:12a[EB 13a]; Dt 33:20; Job 16:9; 18:4; Ps 7:3[EB 2]; 17:12; 22:14[EB 13]; 50:22; Ezk 19:3, 6; 22:25, 27; Hos 5:14; 6:1; Am 1:11; Mi 5:7[EB 8]; Na 2:13[EB 12]+); (nif) be torn to pieces (Ex 22:12b[EB 13b]; Jer 5:6+). (Adamo 2015:62)

The likelihood of that vulnerability arises out of the graphic portraiture of the eagerness of a juvenile lion stealthily pouncing on the unsuspecting prey. All the figurations here collectively encapsulate the vantage position the enemy has over the innocent victim.

\section{A just cause is ultimately pacified through the attainment of divine uprightness 17:13-15}

קוּם (qûm) 'arise' (cf. Ps 7:6; 9:19; 10:12; 44:26), which is onomatopoeic and whose verbosity is common amongst the Orientals of verbs for going, going forward and of setting about anything with impulse (Gesenius \& Tregelles 2003:727), is perhaps appropriate to what has been a carefully calculated presentation of the petitioner's innocence. The appropriateness is derived from the foregoing description of the overwhelming enemy who now has to meet his match in the addressee יהוה (yhwh) understandably invoked by his covenantal name. ${ }^{12}$ The covenantal name grants the petitioner

12.Gesenius and Tregelles (2003:337) recall that יהוה. (yhwh), pr. name of the supreme


the time of Christ, either misled by a false interpretation of certain laws (Ex 20:7; Lv 24:11), or else following some old superstition, regarded this name as so very holy,
that it might not even be pronounced (see Philo, Vit. Mosis t. iii. p. 519, 529). that it might not even be pronounced (see Philo, Vit. Mosis t. iii. p. 519, 529).

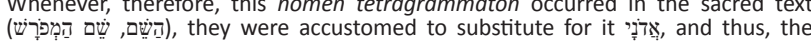

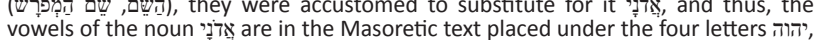
but with this difference, that the initial Yod receives a simple and not a compound access to the full privileges embedded in the covenant here demonstrable from the series of imperatives that ensue compelling God as a trusted party to act on his behalf. The actions here associated with divine intervention as in

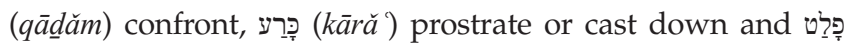
(pālăt ) rescue represent a triumvirate of the Lord's punitive power exercised through his (hěrěb $\underline{\text { ) }}$ sword, often used as a symbol of divine judgement (cf. Ex 15:9; Lv 26:25; 26:33; Num 22:23; Deut 33:29; Is 66:16; Ezr 12:14) (Barry et al. 2012, 2016).

The call to divine intervention seems to be implied in 17:14, though laden with textual problems as attested in Leeven's (1961:48-54) article and subsequently confirmed by other scholars (Craigie 2004:161; Goldingay 2006:244; Weiser 1962:180; Wilson 2002:324), makes a final plea. Without getting lost in the detail of the exceptionally difficult to translate verse, destruction of the enemy is seemingly envisaged here on the one hand, and on the other hand the guarantee of protection of the cherished ones, a translation adopted in the NIV:

O Lord, by your hand save me from such men,

from men of this world whose reward is in this life.

You still the hunger of those you cherish;

their sons have plenty,

and they store up wealth for their children. ${ }^{13}$

The key feature here is noun $\tau_{\tau}^{\prime}(y \bar{a} \underline{d})$ 'hand' which compliments the anthropomorphic attribution of divine intervention seen throughout the psalm (cf. 17:1,6 ear; 17:2, 8 eye(s); 17:4 lips; 17:7 hand; 17:8 wings; 17:15 face). The attribution is the petitioner's strategy to personalise the modality of the sought intervention by appealing to auditory, visual and kinesthetic senses to intimate the idea of imminence.

The petitioner's portrayal of personal uprightness as his terminus comes to the fore in the concluding verse with the appositive אנא 'as for me'. The realistic threat of the enemy far

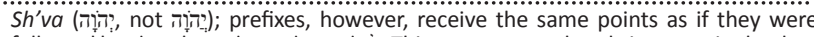

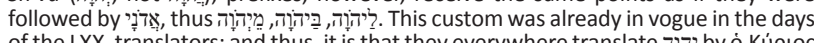
of the LXX. translators; and thus, it is that they everywhere translate bú Kú

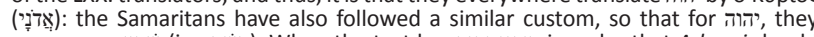

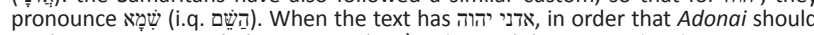

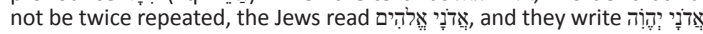

13.Anon (1984) cf. with other translation:

The Holman Christian Standard Bible (HCSV): 'With Your hand, LORD, save me from men, from men of the world, whose portion is in this life: You fill their bellies with what You have in store, their sons are satisfied, and they leave their surplus to their children'.

English Standard Version (ESV): 'from men by your hand, O LORD, from men of the world whose portion is in this life. You fill their womb with treasure; they are satisfied with children, and they leave their abundance to their infants'.

God's Word to the Nations (GWN): 'With your power rescue me from mortals, O LORD, from mortals who enjoy their inheritance only in this life. You fill their $\mathrm{O}$ LORD, from mortals who enjoy their inheritance only in this life. You fill their
bellies with your treasure. Their children are satisfied with it, and they leave what remains to their children'.

King James Version (KJV): 'From men which are thy hand, O LORD, from men of the world, which have their portion in this life, and whose belly thou fillest with thy hid treasure: they are full of children, and leave the rest of their substance to their babes'.

The Septuagint (LXX): 'because of the enemies of thine hand: O Lord, destroy them from the earth; scatter them in their life, though their belly has been filled with thy hidden treasures: they have been satisfied with uncleanness, and have left the remnant of their possessions to their babes'.

New Revised Standard Version (NRSV): 'from mortals- by your hand, O LORD- from mortals whose portion in life is in this world. May their bellies be filled with what you have stored up for them; may their children have more than enough; may they you have stored up for them; may their child
leave something over to their little ones'.

Jewish Publication Society (Tanak): 'from men, O LORD, with Your hand, from men Jewish Publication Society (Tanak): 'from men, O LORD, with Your hand, from men
whose share in life is fleeting. But as to Your treasured ones, fill their bellies. Their sons too shall be satisfied, and have something to leave over for their young'. 
from resolved with only a familiar assurance of divine retribution, the tone of the closure of this lament moots that it is not necessarily the punishment of the enemy through which justice is truly served but the stated personal goal through the apotheosis of seeing the Lord's face in

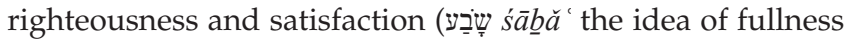
or surfeited) with attaining divine likeness (17:15). The noun

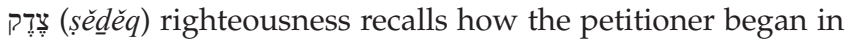
17:1 by utilising the same concept connoting a just cause and now reconfigured to embed a much sought after personal attainment. Righteousness which is sometimes used as a title of the Lord (Jer 23:6; 33:16) or as a concept for justice as the act of fairly deciding what is right in a legal case, without prejudice (Dt 16:20) (Swanson 1997), aptly parallels the concept commanding the psalmist's highest attainment and

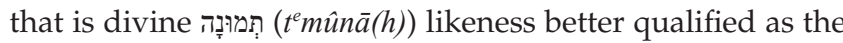
same as (Thomas 1998), or ideas of form, image, likeness, representation and semblance (Strong 1995). Kidner (1973:107) views 'the significance of the righteous for seeing God face to face is not purely judicial ... [but] supreme privilege' (Duet 34:10; Num 12:8). This is where the petitioner finds resolution.

\section{Reflections}

Psalm 17 is a lament by an individual who pleads for divine vindication against an enemy where he presents own uprightness as the basis for the appeal. Some key notable thoughts deserve to be highlighted for purposes of this article.

Firstly, it is the matter of self-declared righteousness common to the psalms of innocence (Ps 17:3-5 cf. 7:4-6, 9; 17; 18:21-25; 26:1, 3-8, 11; 35:13-14; 38:21; 44:21; 86:2; and also in Ps 119:22, $51,55-57,59-62,87,100-102,109-110,121,129,166-168)$. In reading the sentiments expressed elsewhere, the impression given is that the sense of self-declared righteousness emanates, on the one hand, in contrast with the wicked opponents whose attacks are unproved. On the other hand, righteousness is derived from the sense of loyalty to $\mathrm{YHWH}$ demonstrable throughout the psalm. That said, the psalmist is not suggesting the absence of sin in his life, but the courage to redefine a walk with and total reliance on $\mathrm{YHWH}$ as righteousness.

The story that this article commenced with comes to mind. It turns out that the man who formerly enjoyed government protection in his days of dealing so unkindly with others upon his fallout and in times of desperation started attending church services. His desiring of divine intervention was viewed with suspicion and insincerity. His quest for righteousness was not reliant on $\mathrm{YHWH}$ based on a longstanding track record that speaks for itself. In this case, it was desperation derived from loss of former privilege.

Secondly, divine audience and vindication are sought after on the basis of personal pursuit of צ̦ (șéděq) righteousness without which צֶ (șéděq) also translated justice is unobtainable particularly from one whose name is yet again an epitome of צ̦ (séděq) righteousness. Therefore, innocence implies the worthiness of the psalmist's life in YHWH's eyes before whose scrutiny he self presents for affirmation of the fact. It is this attained state of being acquitted of any offence that is strategically utilised in the psalm as a basis for divine audience and intervention. Only such a person can approach the Lord and expect protection, he argues.

At the TED talk recorded on 01 March 2012, Bryan Stevenson ${ }^{14}$ a lawyer by profession, spoke about the American justice system and its disenfranchising of the disadvantaged by stating that:

It's a system that treats you much better if you're rich and guilty than if you're poor and innocent ... In many parts of this country, the opposite of poverty is not wealth. In too many places the opposite of poverty is justice. (Adamo 2015:62)

In surmising his observations, justice could simply begin with being afforded the opportunity to be heard. Africa has numerous cases illustrative of justice delays that amount to justice denials as in the case of Mrs Grace Mugabe's diplomatic immunity for allegedly beating up and injuring 20-year-old Gabriella Engels who was apparently partying with her two sons..$^{15}$ The man in referred to in the opening story would certainly have similarly victimised certainly during his heydays who would have no legal recourse given the implied immunity and a sense of invincibility.

Thirdly, personal uprightness is actually a declaration of a justifiable cause unlike the enemy's intents. Righteousness is encapsulated through honest lips $(17: 1,3)$ and a pure heart (1:3) as the focal points interrogation for both the appellant and the antagonist (17:10). The heart in the seat of thoughts, designs and disposition (Kwakkel 2002:83) shows up in the stances taken by the psalmist and his opponent. Standards of uprightness are universally applied by the psalmist in articulating grounds for fairness or equity. Both the petitioner and the unnamed enemy are subjected to the same tests through which the content of their hearts will accordingly be disclosed. The uprightness of the petitioner, on the one hand, commands divine audience, whilst the deceitfulness of the enemy, on the other hand, provokes divine attention. For the enemy, a just cause is undeserved except in the punishment to be executed in defence of the upright.

The combination of the powerful and guilty perpetrator against an innocent and vulnerable victim presented in the psalm is reminiscent of contemporary scenarios of utter absence of recourse. It plays out in what are sometimes dubbed David versus Goliath cases where an individual unprecedently takes up a case against a powerful corporation. The Amadiba community near Xolobeni, in the Wild Coast of South Africa, provides parallel material where an Australian company is trying to mine the titanium-rich mineral sands

14. Bryan Stevenson spends most of his time in jails and prisons and on death row. He is a lawyer, and the founder of the Equal Justice Initiative. See http://blog.ted.com/ all-of-our-survival-is-tied-to-the-survival-of-everyone-bryan-stevenson-atted2012/

15.See the full account on Times Live 20 August 2017 https://www.timeslive.co.za/ politics/2017-08-20-dirco-confirms-grace-mugabe-has-been-granted-diplomaticimmunity/ 
perhaps at the exclusion of the community's welfare. ${ }^{16}$ As in the petitioner's case, these accounts tend to leave the victim of such circumstances in a state of paralysis where intervention by another party better positioned to handle the enemy is urgently sought. And similarly, the unnamed victims of the man in the opening story would have experienced similar immobility against his perceived indomitable status.

Fourthly, the enemy's punishment does not occupy the petitioner's attention as the just cause is not necessarily realised through that punitive measure. That, as McCann Jr (1996:742) says, places the antagonist in different light. With seeing God's face being viewed positively as the appropriate goal of the righteous, to borrow Wilson's (2002:319) words, people I was talking to in Chad did not necessarily bring into focus the punishment of the man in question as justice served. On the contrary, it would have been learning the necessary life lessons that were seen as just. Similarly, in typical lament fashion, the oppressor remains anonymous. His anonymity serves to underscore that the focal point of justice is not the enemy's demise per se, even though retribution is expected in tangible and material form. Even if we are to refer to David's circumstances mentioned in the superscription prior to his ascension to the throne, and thereafter, his life is mostly decorated for his courage in dealing with his adversaries human and otherwise (1 Sm 17:34-37, 50; 23:1-6; 25:32-34; 30:1-20). The only enemy who was untouchable for David was Saul (1 Sm 24:1-22; 26:1-25) in recognition of the latter's divinely appointed kingship. In fact, David's flight from Saul minimally fits the details described in the psalm. That sort of threat which was unprovoked and from someone least expected be a progenitor of strife motivates why the demise is not focused upon in this psalm. For that reason, the real threat of the enemy is not the lifethreatening or violent attacks which if David's prowess is brought to the fore would have been able to avert, but the ruinous potential of such an attack on demands for attaining a righteous walk.

Similarly, the identity of oppressor, introduced in 17:7 as an opponent of those who trust in the Lord, aptly described as one 'who rises against' the upright (17:7), who potentially threatens the righteous and covenantal relationship between the psalmist and Yahweh (17:8-9), who, through his pride and arrogance as well as secrecy in his modus operandi towards destructive intentions, thwarts the movement of the righteous, is immaterial. So, even when the action is called popon for God to arise (qûm), with swords or any manner of arsenal, the emphasis is on deliverance from the enemy's attacks not necessarily his destruction. The terminus is not defeat or subjugation of the wicked, but the psalmist's continued attainment of uprightness (vs 1, 2, 3, 4, 5, 7, 15).

16 The story that broke out on 22 November 2018 indicates the unprecedented court ruling in favour of the community given the rights to decide what they want done with the land (see https://www.dailymaverick.co.za/article/2018-11-22-wildwith the land (see https://www.dailymaverick.co.za/article/2018-11-22-wild-
coast-community-wins-15-year-david-and-goliath-battle-against-australianmining-company/)
We observe with Leiter (1995) the following:

[The lament] pattern normally consists of an address to God, a complaint, a confession of trust, a petition, words of assurance, and a vow of praise ... A phenomenon in the lament psalm which has fascinated many scholars is the abrupt shift from lament to praise. At the conclusion of many of the laments, the tone of sorrow and lamentation comes to an end, and the psalmist suddenly breaks into joyous praise. (p. 44)

Psalm 17 is somewhat an exception. The conclusion is not a sudden outbreak of praise but satisfaction in uprightness that emanates from Yahweh. If nothing inhibits this attainment, then justice is truly served.

\section{Acknowledgements Competing interests}

The author declares that no competing interests exist.

\section{Author's contributions}

All work is original, and any cited sources have been referenced. S.S.N. was the sole author of this article.

\section{Ethical consideration}

This article followed all ethical standards for a research without direct contact with human or animal subjects.

\section{Funding information}

This research received no specific grant from any funding agency in the public, commercial or not-for-profit sectors.

\section{Data availability}

Data sharing is not applicable to this article as no new data were created or analysed in this study.

\section{Disclaimer}

The views and opinions expressed in this article are those of the author and do not necessarily reflect the official policy or position of any affiliated agency of the author.

\section{References}

Adamo, D.T., 2007, 'Decolonizing the Psalter in Africa', Black Theology 5(1), 20-38. https://doi.org/10.1558/blth.2007.5.1.20

Adamo, D.T., 2015, 'The task and distinctiveness of African Biblical Hermeneutic(s)', OTE 28(1), 31-52. https://doi.org/10.17159/2312-3621/2015/v28n1a4

Anon, 1984, The Holy Bible: New International version, Zondervan, Grand Rapids, MI.

Barry, J.D., Mangum, D., Brown, D.R., Heiser, M.S., Custis, M. \& Ritzema, E., 2012, 2016, Faithlife study bible, Lexham Press, Bellingham, WA.

Becket, J., 2016, 'Lament in three movements: The implications of Psalm 13 for justice and reconciliation', Journal for Spiritual Formation and Soul Care 9(2), 207-218. https://doi.org/10.1177/193979091600900206

Bediako, K., 1995, Christianity in Africa: The renewal of non-Western religion, Edinburg University, Edinburg.

Bediako, K., 2004, 'Review of Holter, Knut Old Testament research for Africa: A critical analysis and annotated bibliography of Old Testament dissertations, 1967-2000', International Bulletin of Missionary Research 28(3), 138. https://doi. org/10.1177/239693930402800318

Bergant, D., 2013, Psalm 1-72 (New Collegeville Bible Commentary Volume 22), Saint John's University, Collegeville, PA. 
Bratcher, R.G. \& Reyburn, W.D., 1991, A translator's handbook on the book of Psalms, United Bible Societies, New York, NY.

Brueggemann, W., 1995, The Psalms and the life of faith, Fortress Press Books, Minneapolis, MN

Charney, D., 2013, 'Maintaining innocence before a divine earer: Deliberative rhetoric in Psalm 22, Psalm 17 and Psalm 7', Biblical Interpretation 21(1), 33-63. https:// doi.org/10.1163/15685152-1041A0003

Coertze, S.V., 2008, 'The African Agent: The recognition and involvement of the African Biblical Interpreter in Bible translation', Verbum et Ecclesia 29(1), 77-90. https://doi.org/10.4102/ve.v29i1.6

Craigie, P., 2004, Psalm 1-50 (Word Biblical Commentary), Grand Rapids, Zondervan.

deClaisse-Walford, N.L., Jacobson, R. \& Tanner, B., 2014, The Book of Psalm (New International Commentary of the Testament), Eerdamans, Grand Rapids, MI.

Gesenius, W. \& Tregelles, S.P., 2003, Gesenius' Hebrew and Chaldee Lexicon to the Old Testament scriptures, Bagster, London.

Goldingay, J., 2006, Psalms (Volume 1: Psalm 1-41), Baker Academic, Grand Rapids, MI.

Graigie, P.C., 2004, Psalm 1-50 (Word Biblical Commentary), Word Books, Waco, TX.

Grogan, G.W., 2008, Psalms (Two Horizons Commentary), Eerdamans, Grand Rapids,

Holter, K., 2002, Old Testament research for Africa: A critical analysis and annotated bibliography of African Old Testament dissertations, 1967-2000, Peter Lang, New York, NY

Holter, K., 2006, Let my people stay! Researching the Old Testament in Africa: Report from a research project on Africanisation of Old Testament studies, Action, Nairobi.

Keil, C.F. \& Delitzsch, F., 1996, Commentary on the Old Testament, Hendrickson, Peabody, MA.

Kidner, D., 1973, Psalms 1-72 (classic commentaries), IVP, Downers Grove, IL.

Kwakkel, G., 2002, According to my righteousness: Upright behaviour as grounds for deliverance in Psalms 7, 17, 18, 26, and 44, Brill, Leiden.

Landes, G.M., 2001, Building your Biblical Hebrew vocabulary: Learning words by frequency and cognate, Society of Biblical Literature, Atlanta, GA.

Leiter, D., 1995, 'Rhetoric of praise in the Lament Psalm', Brethren in Life and Thought $40(1), 44-48$
Lenzi, A., 2010, 'Invoking the God: Interpreting invocations in Mesopotamian prayers and biblical laments of the individual', Journal of Biblical Literature 129(2), 303-315. https://doi.org/10.2307/27821021

Leveen, J., 1961, 'Textual Problems of Psalm 17', Vetus testamentum 11(11), 48-54.

McCann, J.C. Jr., 1996, The new interpreter's Bible volume IV: $1 \& 2$ Maccabees, introduction to Hebrew Poetry, Job, Psalms, Abingdon Press, Nashville, TN.

McComiskey, T.E., 1999, 'ביבָ 78 ', in R.L. Harris, G.L. Archer Jr., \& B.K. Waltke (eds.), Theological wordbook of the Old Testament, Electronic Edition, Logos.

Rankin, E., 2003, 'Africanising Christian imagery in Southern African missions', English in Africa 30(2), 85-100.

Stevenson, B., 2012, 'TED Talk', viewed 15 February 2019, from http://blog.ted.com/ all-of-our-survival-is-tied-to-the-survival-of-everyone-bryan-stevenson-atted2012/.

Strong, J., 1995, Enhanced Strong's Lexicon, Libronix, electronic resource.

Sumpter, P., 2013, 'The coherence of Psalms 15-24', Biblica 94(2), 186-209.

Swanson, J., 1997, Dictionary of Biblical languages with semantic domains: Hebrew (Old Testament), Faithlife, Bellingham, WA.

Thomas, R.L., 1998, New American standard Hebrew-Aramaic and Greek dictionaries: Updated edition, Foundation Publications, California.

Times Live, 2017, 'Dirco confirms Grace Mugabe has been granted diplomatic immunity', viewed 20 August 2017, from https://www.timeslive.co.za/politics/2017-08-20dirco-confirms-grace-mugabe-has-been-granted-diplomatic-immunity/.

Waltner, J.H., 2006, Psalms (believers church bible commentary), Herald Press, Rocky Hill, CT.

Weiser, A., 1962, The Psalms (translated by Herbert Hartwell): The Old Testament library, SCM Press, Philadelphia, PA.

Whitaker, R., Brown, F., Driver, S.R. \& Briggs, C.A., 1906. The abridged Brown-DriverBriggs Hebrew-English Lexicon of the Old Testament: From A Hebrew and English Lexicon of the Old Testament by Francis Brown, SR Driver and Charles Briggs, based on the Lexicon of Wilhem Gesenius, Hughton Mifflin Company, Boston, MA.

Wilson, G.H., 2002, The NIV application commentary: Psalms volume 1, Zondervan, Grand Rapids, MI.

Wiseman, D.J., 1999, '930 רשָׁיָ', in R.L. Harris, G.L. Archer Jr. \& B.K. Waltke (eds.), Theological wordbook of the Old Testament [Electronic Edition], Moody Press, Chicago, IL.

Younan, M.A., 2011, 'Do justice, love kindness, walk humbly: Just peace in the middle east', The Ecumenical Review 63(1), 25-34. https://doi.org/10.1111/j.1758$6623.2010 .00090 \cdot x$ 